\title{
The Preparation of Color Glasses Using the Solid Waste Generated in Crystalline Silicon Cutting Process
}

\author{
Zhi LIU ${ }^{\mathrm{a}}$ and Shi-quan LIU, ${ }^{\mathrm{b}}$ \\ School of Materials Science and Engineering, University of Jinan, Jinan 250022, Shandong, China \\ a275754537@qq.com, bliusq_ujn@hotmail.com \\ *Corresponding author: Shiquan Liu
}

\begin{abstract}
Solid waste generated in crystalline silicon cutting process (referred to as the silicon waste) was used to prepared color glasses. Silicon carbide and silicon in the silicon waste acted as silicon source and iron fragments as coloring agent. All components in the waste were fully used by vitrification of the solid waste with addition of $\mathrm{Na}_{2} \mathrm{CO}_{3}, \mathrm{CaO}$, etc. The highest content of the silicon waste was $44.97 \%$ in the glass batch. The prepared color glasses can absorb part of visible light and ultraviolet light.
\end{abstract}

Keywords-cutting of crystalline silicon; solid waste; color glass; absorption of ultraviolet light

\section{INTRODUCTION}

Silicon waste is generated during the cutting process of crystalline silicon. The waste mainly contains silica carbide, crystalline silicon, iron and its oxide, polyethylene glycol (PEG) [1-2]. There are many reports on the recycling of SiC and PEG in the waste. PEG is collected by dehydrating or distilling the liquid after solid-liquid separation of cutting slurry. Afterwards, the solid is dissolved in acid to remove iron and $\mathrm{Si}, \mathrm{SiC}$ fine powder is left behind [3-7]. The recovery of crystalline Si is still a challenge. Alternatively, the silicon waste was used for the preparation of ceramics, building materials. The above studies provided directions for the reuse of the silicon waste. However, these processes are complex, high cost, time-consuming, and the waste cannot be fully utilized. Therefore, it is necessary to find a new recycling method for this silicon waste.

In this work, silicon waste was used for the preparation of color glasses. All components in the silicon waste were used without complex separation and purification. The prepared color glasses have high additional value.

\section{EXPERIMENTAL SECTION}

Chemical composition of the silicon waste is shown in Table I. Sodium carbonate, calcium oxide and other raw materials were analytical reagents. Silicon waste was ground in a planetary ball mill with $250 \mathrm{rpm}$ for $30 \mathrm{~min}$, and then was sieved to pass a 200 mesh sieve. In some cases, the waste was pretreated by calcined at $350{ }^{\circ} \mathrm{C}$ for $2 \mathrm{~h}$, and then at $1500{ }^{\circ} \mathrm{C}$ for $2 \mathrm{~h}$.
TABLE I. CHEMICAL COMPOSITION OF THE SILICON WASTE

\begin{tabular}{|c|c|c|c|c|c|c|c|}
\hline Component & $\mathrm{SiC}$ & $\mathbf{S i}$ & $\mathbf{F e}$ & $\mathrm{Al}_{2} \mathrm{O}_{3}$ & $\mathbf{C u O}$ & $\mathbf{C a O}$ & $\begin{array}{c}\text { Un- } \\
\text { known }\end{array}$ \\
\hline $\mathrm{wt} \%$ & 62.51 & 27.49 & 8.58 & 0.38 & 0.31 & 0.25 & 0.48 \\
\hline
\end{tabular}

The designed chemical composition of the glasses is shown in Table II. The preparation procedures were as follows. First, the silicon waste and other raw materials were weighed and uniformly mixed to form glass batches. The glass batches were melted in silica crucibles in an electrical furnace at $1350{ }^{\circ} \mathrm{C}-1550{ }^{\circ} \mathrm{C}$ for $2 \mathrm{~h}$. The melts were directly poured into a preheated steel plate for forming. Finally, the bulk glasses were annealed at $600^{\circ} \mathrm{C}$ for $2 \mathrm{~h}$.

TABLE II. DESIGNED COMPOSITION OF THE GLASSES

\begin{tabular}{|c|c|c|c|c|c|c|c|}
\hline \multirow{2}{*}{$\begin{array}{c}\text { The NO. } \\
\text { Glass }\end{array}$} & \multicolumn{7}{|c|}{ Designed composition } \\
\cline { 2 - 8 } & $\mathrm{SiO}_{2}$ & $\mathrm{Na}_{2} \mathrm{O}$ & $\mathbf{C a O}$ & $\mathrm{Fe}_{2} \mathrm{O}_{3}$ & $\mathrm{Al}_{2} \mathrm{O}_{3}$ & $\mathbf{M g O}$ & else \\
\hline 1 & 66.08 & 16.60 & 9.06 & 1.89 & 1.51 & 3.02 & 1.84 \\
\hline 2 & 57.22 & 20.95 & 11.43 & 2.38 & 1.90 & 3.81 & 2.31 \\
\hline 3 & 55.87 & 20.47 & 11.16 & 4.65 & 1.86 & 3.72 & 2.27 \\
\hline 4 & 54.10 & 21.47 & 11.71 & 4.50 & 1.95 & 3.90 & 2.37 \\
\hline
\end{tabular}

The X-ray diffraction analysis (D8 ADVANCE, Bruker, Germany) was used for identifying the crystalline phase in the silicon waste before and after the pretreatment. The density of bulk glasses were measured by the Archimedes method using a density analytical balance (FA1004J, Xu hui, China). The spectra of the colored glasses were recorded on a visible spectrophotometer (721, Jing hua, China). 


\section{RESULTS AND DISCUSSION}

\section{A. The XRD Analysis of the Silicon Waste}

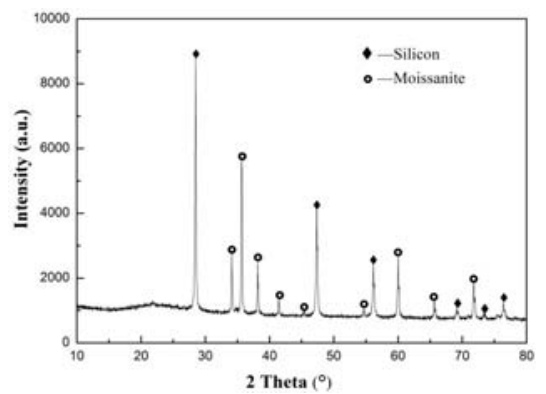

Figure 1. XRD pattern of the silicon waste

Fig. 1 shows the XRD pattern of the silicon waste. The main crystalline phases are SiC (JCPDF card No. 74-1302) and Si (JCPDF card No. 27-1402). The relative contents Si and $\mathrm{SiC}$ are respectively $30.54 \%$ and $69.46 \%$, calculated by internal standard method using $\mathrm{Si}$ as the standard sample.

Crystalline silicon can be melted above $1410{ }^{\circ} \mathrm{C}$ [8]. However, the melting point of crystalline silicon carbide is above $2700{ }^{\circ} \mathrm{C}$, which is difficult to melt alone.

\section{B. The Formation of Glass}

Silicon waste alone cannot be melt into a glass due to the refractory SiC. It should be mixed with other raw materials. From glass 1 to 3, the content of the silicon waste were $13.04 \%, 16.21 \%$, $35.26 \%$ in the batch, respectively. The melting temperatures for preparing the glasses were $1350{ }^{\circ} \mathrm{C}, 1450{ }^{\circ} \mathrm{C}, 1500{ }^{\circ} \mathrm{C}$, respectively, which are increasing due to the differences in the content of the refractory $\mathrm{SiC}$ brought by the silicon waste. When a small amount of silicon waste was added, refractory $\mathrm{SiC}$ can be slowly oxidized at high temperature [9-10]. In this case, this batch can be melted into glass. However, when silicon waste without pretreatment was used as the glass raw material, its content could only be up to $35.3 \%$ in the glass batch. It is difficult to form glass while the content of the silicon waste is higher.

\section{Density}

The densities of glasses No. 1, 2 and 3 are respectively $2.60 \mathrm{~g} / \mathrm{cm}^{3}, 2.64 \mathrm{~g} / \mathrm{cm}^{3}, 2.66 \mathrm{~g} / \mathrm{cm}^{3}$. It can be seen that the density of the colored glass increases with the increase of the silicon waste. The higher the content of the silicon waste was used, the more $\mathrm{Fe}_{2} \mathrm{O}_{3}$ was formed in the glass (see the latter discussion). Therefore the glass density increased.
D. Spectral Characteristics

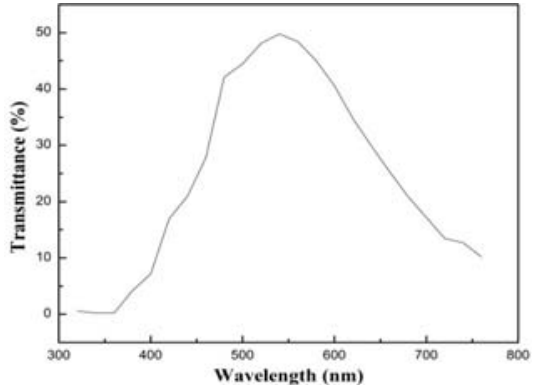

(a)

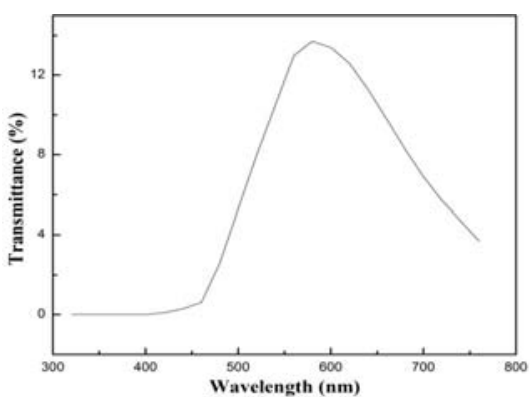

(b)

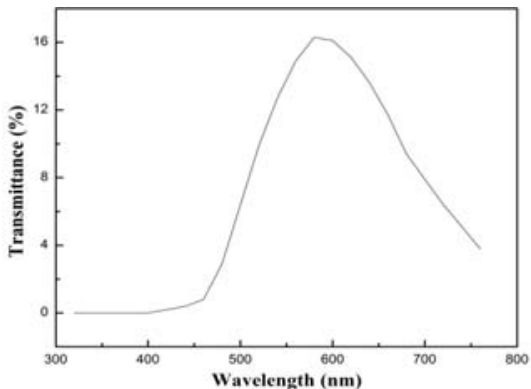

(c)

Figure 2. Spectra of the glasses 1 (a), 2 (b) and 3 (c)

The spectra of the glasses 1, 2, 3 are shown in Fig. 2. From the Fig. 2a, we can see that maximum transimmison of glass 1 is at $540 \mathrm{~nm}$ and the color of the glass 1 is light yellow-green. The glass absorbs ultraviolet light below $370 \mathrm{~nm}$. With increasing the content of silicon waste, glasses 2 and 3 shows maximum transimision at about 580nm (Fig. $2 \mathrm{~b}, \mathrm{c})$ and the color is yellow-green.

\section{E. The Glass Prepared with Pretreated Waste}

$\mathrm{SiC}$ and $\mathrm{Si}$ in the silicon waste are not conventional glass raw materials. If the silicon waste was used in a large amount in the preparation of glasses, some of the components in the silicon waste cannot be easily melt and mixed with other glass components and hindering the formation of glass during the melting process. The above study has shown that use of the waste used to prepare glass is low. However, after the pretreatment of the waste, the amount of waste in the glass batch can be greatly increased. 


\section{F. Phase Transition}

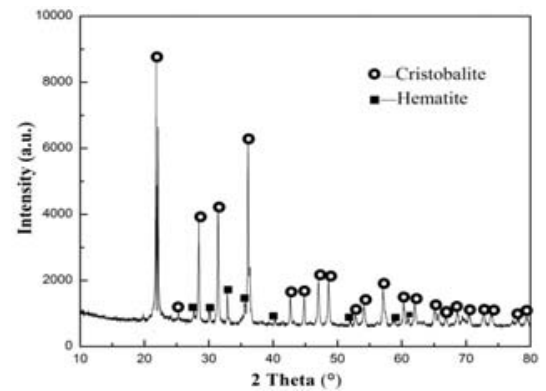

Figure 3. XRD patterns of the silicon waste after pretreatment

After the pretreatment, $\mathrm{SiC}$ and $\mathrm{Si}$ in the silicon waste were oxidized into $\mathrm{SiO}_{2}$ (JCPDF card No. 82-1403) (Fig. 3). A new crystalline phase $\mathrm{Fe}_{2} \mathrm{O}_{3}$ (JCPDF card No. 99-0060) was found. The result suggests iron existed in the original silicon waste. It was brought by the saw line used in the cutting instrument. However, it was not identified in Fig. 1. The reason is that the iron content in the silicon waste was below the XRD detection limit. The chemical composition of the silicon waste after the pretreatment is presented in Table III.

TABLE III. CHEMICAL COMPOSITION OF THE SILICON WASTE AFTER PRETREATMENT

\begin{tabular}{|c|c|c|c|c|c|}
\hline \multirow{2}{*}{$\begin{array}{c}\text { Silicon } \\
\text { waste }\end{array}$} & \multicolumn{5}{|c|}{ Chemical composition after pretreatment } \\
\cline { 2 - 6 } & $\mathrm{SiO}_{2}$ & $\mathrm{Fe}_{2} \mathrm{O}_{3}$ & $\mathrm{Al}_{2} \mathrm{O}_{3}$ & $\mathrm{Na}_{2} \mathrm{O}$ & Else \\
\hline wt \% & 94.86 & 4.42 & 0.19 & 0.16 & 0.37 \\
\hline
\end{tabular}

In Table III, we cannot found the refractory SiC in the silicon waste. It was oxidized into $\mathrm{SiO}_{2}$ which is favorable for the glass formation. In addition, the oxidation degree of iron can affect the color of the prepared glass. The composition of the pretreated silicon waste conforms to the requirements of the oxide glass forming region. This makes it possible to use massive silicon waste in glass preparation.

\section{G. The Formation of Glass}

When the pretreated silicon waste was used as a glass raw material, its content can be increased to $44.97 \%$ in the glass batch. The utilization of the silicon waste is improved remarkably. Meanwhile, when the pretreatment silicon waste is used, glass can be prepared at a low temperature. Glass No.4 was melted at $1350{ }^{\circ} \mathrm{C}$, although it was derived from a batch contained much higher content of silicon waste than glasses $1 \sim 3$. The density of this glass is $2.70 \mathrm{~g} / \mathrm{cm}^{3}$, larger than those of glasses $1 \sim 3$ mainly due to the high inclusion of $\mathrm{Fe}_{2} \mathrm{O}_{3}$.

\section{H. Spectral Characteristics}

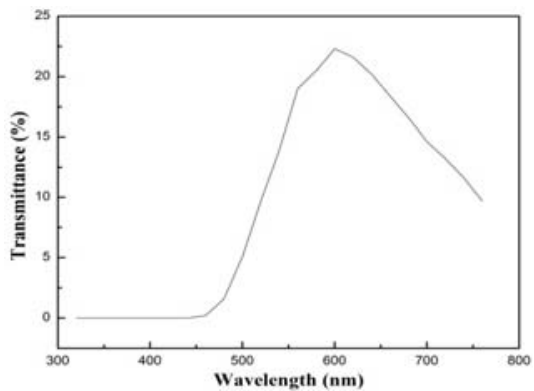

Figure 4. Spectrum of the glass 4

The maximum transmission of glass 4 (Fig. 4) is at about $600 \mathrm{~nm}$ and its color is brown. The glass absorbs visible light and ultraviolet light below 460nm.

The prepared colored glasses can express different colors from yellow-green to brown -yellow according to the valence and content of iron ions. All the glasses absorb ultraviolet light.

\section{CONCLUSIONS}

Silicon waste generated during the cutting process of crystalline silicon can be used to prepare color glasses. No other additional colorant is needed and the production cost is low. The obtained glass adsorbed ultraviolet light. Using the original solid waste, its content in glass batch can only be up to $35.3 \%$ and the melting temperature is up to $1500{ }^{\circ} \mathrm{C}$. However, the pretreatment of the silicon waste turned refractory $\mathrm{SiC}$ into $\mathrm{SiO}_{2}$, which benefits the inclusion of silicon waste of in the glass batch up to $44.97 \%$ and the melting temperature is $1350{ }^{\circ} \mathrm{C}$.

\section{REFERENCES}

[1] H. Wu, "Wire sawing technology: A state-of-the-art review," Precision Engineering, Vol. 43, Jan. 2016, pp. 1-6, doi: 10.1016/j.precisioneng.2015.08.008.

[2] L. Zhang, A. Ciftja, "Recycling of solar cell silicon scraps through filtration, Part I: Experimental investigation," Solar Energy Materials and Solar Cells, Vol. 92, Nov. 2008, pp. 1450-1461, doi: 10.1016/j.solmat.2008.06.006

[3] J. Tao, S. Yu, "Review on feasible recycling pathways and technologies of solar photovoltaic modules," Solar Energy Materials and Solar Cells, Vol. 141, Oct. 2015, pp. 108-124, doi: 10.1016/j.solmat.2015.05.005.

[4] N. Guerfia, N. Drouichea, S. Medjaheda, M. Hamoub, F. Sahraoui, "Disposal of metal fragments released during polycrystalline slicing by multi-wire saw,” Journal of Crystal Growth, Vol. 447, Aug. 2016, pp. 27-30, doi: 10.1016/j.jcrysgro.2016.04.017.

[5] H. Wang, Y. Tan, J. Li, Y. Li, W. Dong, "Removal of silicon carbide from kerf loss slurry by Al-Si alloying process," Separation and Purification Technology, Vol. 89, Mar. 2012, pp. 91-93, doi: 10.1016/j.seppur.2012.01.021.

[6] H. Gopala K. Murthy, "Evolution and present status of silicon carbide slurry recovery in silicon wire sawing," Resources, Conservation and Recycling, Vol. 104, Nov. 2015, pp. 194-205, doi: 10.1016/j.resconrec.2015.08.009.

[7] Y. Lee, S. Jeong and S. Park, "Study on manufacturing of recycled $\mathrm{SiC}$ powder from solar waferingsludge and its application," 
International Journal of Precision Engineering and ManufacturingGreen Technology, Vol. 1, Oct. 2014, pp. 299-304, doi: 10.1007/s40684-014-0036-x.

[8] H. Nguyen, V. Hoang, L. Minh, "Melting of crystalline silicon thin films," Computational Materials Science, Vol. 89, Jun. 2014, pp. $97-$ 101, doi: 10.1016/j.commatsci.2014.03.039.
[9] L. Jia, H. Zhang, S. Li, X. Jia, "Effect of particle size on oxidation of silicon carbide powders,” Ceramics International, Vol. 33, Mar. 2007, pp. 309-313, doi: 10.1016/j.ceramint.2005.09.014.

[10] X. Hou, G. Zhang, K. Chou, "Influence of particle size distribution on oxidation behavior of SiC powder," Journal of Alloys and Compounds, Vol. 477, May. 2009, pp. 166-170, doi: 10.1016/j.jallcom.2008.10.029. 